\title{
STRUKTURALIZM I HISTORIA
}

\author{
BARTŁOMIEJ BEESZNOWSKI
}

Doskonale znana jest waga psychoanalizy, etnologii czy lingwistyki Ferdinanda de Saussure'a w uformowaniu się po drugiej wojnie światowej paradygmatu strukturalistycznego we Francji. Te trzy dziedziny (wspomagane przez demaskatorską, wywodzącą się z marksizmu, genealogiczną metodę interpretacji ideologii, której sednem jest krytyka ekonomii politycznej) odwróciły wzrok ówczesnych adeptów filozofii i nauk społecznych od badania fenomenologicznej rzeczywistości samoświadomego podmiotu. Zwróciły go przy tym nie tyle ku regionom niejasnym i mrocznym - mitycznej „podświadomości” - ile ku polu formowania się tego, co najbardziej oczywiste, jasne i zewnętrzne, a przez to niemogące zostać ujęte w słowach - czyli nieświadomości. Jak pisał o niej Michel Foucault w 1966 roku : ,już jest, ale pozostaje w ukryciu, istnieje w niemej trwałości rzeczy, zamkniętego w sobie tekstu, luki w widzialnym tekście” (Foucault 2007, 336). „Odkrycie nieświadomości”, stanowiące znamienny moment rozwoju dziewiętnastowiecznej nauki o człowieku i kulturze, w swych rozmaitych wymiarach - psychologicznym u Sigmunda Freuda, ekonomicznym u Karola Marksa, etycznym u Friedricha Nietzschego, później zaś w powiązaniu tego, co językowe z tym, co społeczne u Ferdinanda de Saussure'a oraz Claude’a Lévi-Straussa - dało początek serii rozważań, które podstawowy przedmiot nauk o człowieku ulokowały poza świadomością poznającego podmiotu, jednak nie „poza podmiotem samym”.

\footnotetext{
${ }^{1}$ W tym samym roku Jacques Lacan wydał swe słynne Écrits.
} 
Powiązanie języka i nieświadomości, które w zalążkowej postaci występuje już w antropologii Marcela Maussa, w pełni rozwinięte zostało w Lacanowskiej, potem zaś Derridiańskiej reinterpretacji teorii lingwistycznej de Saussure’a (Strozier 2013, 21). Francois Dosse zauważył, że strukturalistyczna metodologia polegająca na wiązaniu symptomów i znaków z głębszym, ponadjednostkowym i strukturalnym wymiarem reguł rządzących formowaniem się kultury stanowiła nie tylko pewien rodzaj naukowej idée fixe. Tropienie nieświadomego stanowiło także element „ducha czasów”, zwróconego przeciwko tradycyjnym wartościom zachodniej kultury ostrza krytyki, które w tym, co niewidoczne, nieme i wyparte poszukiwało momentu genetycznego (Dosse 1997, xx). Jak pisał jeszcze w 1973 roku Gilles Deleuze: „[...] rzeczy maja strukturę tylko o tyle, o ile wygłaszaja bezgłośne mowy w języku znaków” (Deleuze 1978, 287).

Podobnie jak dla Kanta - dla Lévi-Straussa, „papieża strukturalistów”, główna stawką nauki miało być odniesienie transcendentalnych kategorii poznania do skończonego bytu ludzkiego. W tym sensie wczesny strukturalizm stanowił jeszcze późne dziecko osiemnastowiecznej tradycji oświeceniowej, obarczonej tymi samymi grzechami, które znamionowały także - wyszydzoną później przez kolejne pokolenia myślicieli - psychoanalizę i niektóre odmiany marksizmu. Wszystkie one - stanowiąc element epoki - starały się jednak, unikając pułapek substancjalizacji czy esencjalizacji, ocalić podmiotowość, wprowadzając ja niejako tylnymi drzwiami jako instancję realizująca bezosobowe struktury poprzez swoista mediację, nośnik generatywnych skryptów stanowiących „naturalne dziedzictwo ludzkości” (ten pogląd stanowi jedno z najdłużej utrzymujących się przekonań strukturalistycznej teorii języka, np. w teorii gramatyki transformacyjno-generatywnej Noama Chomsky'ego). Stanowisko to spotkało się z ostrą krytyką ze strony kolejnej generacji filozofów - Barthes'a, Deleuze'a, Derridy, Foucaulta - dla których krytyka podmiotu z konieczności pociagała za sobą krytykę tego, co dla tradycji strukturalistycznej stanowiło o pracy i dynamice kultury tj. głębi nieświadomych, uniwersalnych i bezosobowych struktur.

Odrzucenie Cogito nie opiera się jednak na prostej konstatacji odmawiającej Kartezjańskiej hermeneutyce pewności, ostatecznego ugruntowania, zaś Kantowską krytykę transcendentalną określającej jako projekt przerwany w pół drogi. Więcej, krytyka Kartezjusza i Kanta wynika nie tylko z odrzucenia klasycznego podmiotu myślącego. To raczej owo odrzucenie podmiotu i psychologicznej głębi człowieka spowodowane jest odkryciem „innego” podmiotu, który ukrywa się na powierzchni języka, niepokojącego sobowtóra znajdującego się za maską symbolu. Poststrukturaliści odkryli, że tym, co mówi jest sam język. Dyskurs wypowiada tak naprawdę sam siebie, a mowa to narzędzie zakrywające wirtualną naturę podmiotu wypowiedzi, którym jest sama struktura. „Przed wszelkim ludzkim myśleniem byłaby już jakaś wiedza, jakiś system, który my dopiero odkrywamy" (Foucault 2013, 35). 
Wydaje się, że podobnie jak wpływ klasycznego językoznawstwa (de Saussure, szkoła moskiewska i praska), tak i francuska interpretacja psychoanalizy miała ogromny wpływ na koncepcję „bezosobowego” podmiotu, która stanowi niewątpliwie jeden z wyróżników strukturalizmu jako swego rodzaju metody epistemologicznej. Psychoanaliza szczególnie Lacanowska interpretacja dzieła Freuda - była niewątpliwie kamieniem probierczym całego pokolenia, które afirmowało, dyskutowało, rozwijało, później zaś odrzucało tezy Freuda i Lacana. Nawet w latach siedemdziesiątych dwudziestego wieku, krytyczni już wobec roli, jaką strukturalizm i psychoanaliza odegrały w dziejach myśli, Gilles Deleuze i Félix Guattari, nie odżegnywali się od dziedzictwa Lacana, postrzegając swoja pracę jako krytyczne przepracowanie jego teorii dotyczących nieświadomości, języka i kompleksu Edypa przez włączenie w nie czegoś, co stanowiło największą barierę i zarazem szansę dla dotychczasowej krytyki kultury - schizofrenię rozumianą jako multiplikacja sensu, produkcja pragnienia poza edypalną strukturą trójkąta rodzinnego. Swą pracę, podobnie jak Foucault, uznawali oni za materialistyczną krytykę psychoanalizy, stawiająca podstawowe rozpoznania nauki Freuda oraz strukturalizmu ,z głowy na nogi”2.

Podręcznikowe pytania dotyczące linii demarkacyjnej oddzielającej strukturalizm od jego kolejnych wcieleń i wyrosłych na jego gruncie (choć krytycznych wobec niego) kierunków wydają się jałowe. Poststrukturalizm stanowi kategorię bardzo pojemna, lecz niemająca jasno zarysowanego pola pojęciowego i znaczenia. Wydaje się jednak, że użyteczność tego określenia zasadza się nie tyle na jego własnościach periodyzacyjnych, ile na ukazaniu pewnej cezury, która oddziela pewna grupę myślicieli od ich strukturalistycznego korzenia, stanowiąc o specyficznych cechach ich twórczości. Terminem tym - którego źródeł należy szukać głównie w anglosaskiej recepcji myśli francuskich filozofów, takich jak Louis Althusser, Roland Barthes, Jacques Derrida, Jacques Lacan czy Michel Foucault - określamy zbiorczo francuską myśl z lat sześćdziesiątych i siedemdziesiątych odnoszącą się do dokonań klasycznego strukturalizmu językowego Ferdinanda de Saussure’a, Romana Jakobsona czy etnologicznego Marcela Maussa i Claude’a Lévi-Straussa, oraz mitografii Georgesa Dúmezila, a mimo to pozostająca w pewnego rodzaju krytycznej relacji do nich, nie wolnej jednak od zależności czy wręcz twórczej inspiracji. Jak wielokrotnie podkreślano, trudno ostatecznie ocenić, który z wymienionych wyżej myślicieli należał do formacji strukturalistycznej, a który już poza nią wykraczał.

\footnotetext{
${ }^{2}$ Po ukazaniu się pierwszego tomu Kapitalizmu i schįofrenii Deleuze oświadczył: „Sam Lacan mówił przecież: nie starajcie się mi pomagać. My chcieliśmy mu pomóc na sposób schizofreniczny. [...] Nie atakujemy żadnej ideologii, ideologii psychoanalitycznej. Atakujemy raczej samą psychoanalizę, jej praktykę i teorię. Nie ma więc żadnej sprzeczności w tym, że mówimy: to jest coś wspaniałego, a zarazem podkreślamy, że od samego początku coś było nie tak. [...] To nie żadna sprzeczność - zakwita wspaniały kwiat, a jednocześnie od samego poczattku zachodzi proces gnicia (Deleuze 2007, 26, 29)".
} 
Niezależnie od tych rozważań terminologicznych następujące stwierdzenie Vincenta Descombesa wydaje się doskonale oddawać specyficzną funkcję strukturalizmu we francuskiej filozofii: „Strukturalizm jest [...] jedynie mianem metody naukowej. Istnieje jednak niepodważalny wplyw strukturalizmu na dyskurs filozoficzny" (Descombes 1996, 96). „Wpływ” ten, który nie trudno odnaleźć u wielu współczesnych myślicieli (nie tylko francuskich) - coś więcej niż odniesienie, mniej jednak niż bezpośrednie wynikanie - należy z pewnością do podstawowych znamion tego kierunku, trudnego do jednoznacznego zaszufladkowania w kategoriach np. szkoły naukowej. Nie ma wattpliwości, że strukturalizm wywarł także przemożny wpływ na historiografię, zarówno od strony metodologicznej (wspomnijmy tu tylko koncepcję „długiego trwania” wywodzącą się ze szkoły Annales czy koncepcje „zdarzenia” zawartą w pracach Michela Foucaulta i Gilles'a Deleuze'a), jak i epistemologicznej (krytyka postrzegania dziejów jako kumulatywnego, ewolucyjnego czy dialektycznego ciagu i przejście w kierunku myślenia „historycznej historii” jako serii pól wyłaniania zdarzeń). Kategoria „zdarzenia” wydaje się w ostatnim dziesięcioleciu robić szczególną karierę. Pozwala ona myśleć przeszłość jako czas „wyobrażony”, „fantazmatyczny” i pozostajacy w stanie ciąłej redefinicji, jako performatywną mapę, wyznaczająca możliwość stawania się kolejnych fenomenów społecznych i dyskursywnych. Poststrukturaliści sformułowali postulat pisania „historii stawania się", udowadniając, że każda „wielka Historia” jest zawsze tylko pudrem skrywającym otchłań chaosmotycznych relacji. Konieczność historyczna jest zatem jedynie splotem przypadków, przypadek zaś zgodnie z maksymą, którą lubił powtarzać Gilles Deleuze - to kości rzucane przez „żelazną rękę konieczności”.

Jeśli dla klasycznego de Saussure'owskiego strukturalizmu (także antropologii strukturalnej oraz historii „długiego trwania” Fernanda Braudela) konstytutywny był jeszcze podział na strukturę języka (poziom wirtualny i głęboki, który warunkuje możliwości wypowiadania w danej formacji) i wydarzenie mowy (przygodną aktualizację, rezultat strukturalnych zależności), to poststrukturalizm wykracza już poza ten dualizm z dynamiczna teoria wydarzenia jako performatywnej materii historycznej. Historię poststrukturalizm postrzega zatem jako żywioł genetyczny. Sedno tego stwierdzenia kryje się jednak nie tyle w kwestii bycia, nawet nie stawania się, ile przekształcania. Nie idzie tu wszakże znów tylko o przekształcanie jednych osób, wydarzeń, gestów, instytucji i słów, w inne, w następstwie zmiennych sił (nawet jeśli miałyby one oznaczać siły „empiryczne” - społeczne, polityczne czy ekonomiczne), „transcendentalnej struktury losu”. Na tym poziomie poruszalibyśmy się jeszcze gdzieś pomiędzy wulgarnym historyzmem a idealizmem Kantowskiej koncepcji dziejów (a może już gdzieś bliżej dialektycznej wizji Hegla?). Punkt dojścia poststrukturalistów stanowi z pewnością twierdzenie: historia jest żywiołem genetycznym, gdyż jest żywiołem par excellence transcendentalnym, tzn. sama jest historyczna. „A priori 
pozytywności nie jest więc tylko systemem rozproszenia czasowego; również samo stanowi zbiór przekształcalny" (Foucault 2002, 152). Stosunki sił w historii tworzą zatem a priori, ono zaś wyznacza możliwości kolejnych rekonfiguracji tych sił. Czas i przestrzeń w ramach materialistycznie pojmowanej transcendentalności stanowią żywioły historii i ciała. W istocie możemy sobie wyobrażać historię nie jako linię, ale pole, przestrzeń doświadczenia raczej niż następstwo, do tego jeszcze podzieloną na warstwy historyczne - różnorakie reżimy władzy i wiedzy, widzialności i wypowiadalności, które nachodzą na siebie; formacje wzajemnie się przenikające. Mimo że powszechnie postrzegamy następstwo historyczne jako stawanie się rzeczy, w istocie pomiędzy stawaniem się a historią sensu stricto istnieje nieciagłość. „Historia nie jest eksperymentowaniem, to nieledwie zbiór negatywnych warunków umożliwiających eksperymentowanie z czymś, co się historii wymyka. Bez historii eksperyment byłby nieokreślony, pozbawiony podstawy, jednak eksperymentowanie nie jest czymś historycznym" (Deleuze 2007, 176). Przedmiotem historii jako nauki są te właśnie wydarzenia, rozumiane jako praktyki dekonstruujące i rekonstruujące rzeczywistość, jako działania historyczne będące w istocie zarazem praktykami historii, możliwymi „formami historii”, a jednocześnie podlegającymi rozmaitym „historycznym transformacjom”.

Wydaje się, że tak zarysowana perspektywa historiozoficzna poststrukturalizmu zbliża go w sposób znaczący do paradygmatu materializmu historycznego, który w latach pięćdziesiątych i sześćdziesiątych dwudziestego wieku wydawał się istotowo odmienny od metody francuskich filozofów. Jeszcze w 1976 roku polski historyk i metodolog nauk historycznych, Jerzy Topolski odrzucał wszelkie podobieństwa pomiędzy strukturalizmem (do którego zaliczał także Foucaulta) a marksizmem. Za kość niezgody pomiędzy nimi uważał teorię procesu historycznego, mająca dla Marksa „charakter aktywistyczny, tzn. uznająca, że to rzeczywiście ludzie są twórcami historii” (Topolski 1977, 262), dla strukturalistów zaś, zdaniem Topolskiego, historia miała stanowić skrajnie deterministyczny schemat przyznający absolutny prymat bezosobowym strukturom głębokim, rządzącym ludzkimi działaniami, których lokalizacja byłaby sednem metody badawczej. Po latach od tej dyskusji widać już doskonale, że poststrukturalizm, oraz m.in. pozostająca pod jego wpływem włoska marksistowska filozofia polityczna, podjęły i sfalsyfikowały ten problem. Jeżeli w przypadku Marksa „wymiar strukturalny” historii stanowiłyby historycznie świadome - tzn. odnoszące się do konkretnej kulturowej warstwy świadomości historycznospołecznej - skrypty praktyk społecznych, dla Lévi-Straussa zaś ostatecznym punktem dojścia strukturalizmu miałyby być wrodzone biologiczne dyspozycje, nieświadome struktury głębokie, to poststrukturalistyczny materializm polityczny wykracza poza ten dualizm. $Z$ jednej strony wychodzi on w kierunku teorii produkcji i produktywnych urządzeń (pojęcie Foucaulta i Deleuze’a wykorzystane później przez teoretyków z kręgu postoperaistycznego), z drugiej w stronę performatywnego języka politycznego w myśli Paola Virna czy koncepcji 
produkcji podmiotów u Maurizia Lazzarata. Do konstatacji Marksa, że człowiek działa świadomie, ale nie dowolnie, gdyż działa w określonych warunkach historycznych, poststrukturalizm dopowiada: choć nie istnieje zobiektywizowana historia w postaci bezosobowych, uniwersalnych i nieświadomych struktur, działanie człowieka pozostaje od niego niezależne, jednak nie w sensie obiektywnym i deterministycznym, ale „funkcjonalnym”. Oznacza to, że aprioryczne struktury, które same są historycznie zmienne, wyznaczają aktualizujące je działanie podmiotów nie tyle „wpływając na nie”, ile stanowiąc ogólną mapę działań, wzajemnych wpływów i relacji, mówiąc językiem Deleuze’a - wykres władz i przeciwwładz, kodów i dekodowania. Nie istnieje więc ostateczna „przyczyna strukturalna”, ale bezustannie ponawiany wysiłek, opór wobec warunków danej formacji, które „przedstawiają się” nam jako obiektywne i uniwersalne formy, jako konstytutywny „obraz” stosunków społecznych. Odkrycie strukturalizmu ukazujące nieświadomy charakter struktur działania przekuć zatem należy w teorię nieświadomości jako praktyki, a zatem takiego działania, w przypadku którego to właśnie „świadomy” (w sensie marksowskim - „abstrakcyjny”) charakter odgradza nas od historycznej bazy, warunków, jakie nas określaja.

Na czym więc polegać miałaby rola strukturalistycznej pojęciowości dziś? Czy - choć jakiś czas temu nie bez szwanku przeszła ona przez ogień krytyki ze strony jej własnych wychowanków - faktycznie odrzuciliśmy strukturalistyczne pojęcia? A może funkcjonują one w języku aktualnej refleksji na podobnej zasadzie jak koncepcje Marksa, które stały się immanentnym elementem dyskursów współczesnych nauk społecznych (choć ich użytkownicy nie zawsze o tym wiedzą i nie zawsze chcą się do tego przyznawać)? Być może zatem strukturalizm to epistemologiczna podstawa naszego myślenia, która sama winna zostać poddana swoistej wiwisekcji, by umożliwić nam samodzielną analizę tego, co nadchodzi. Taka wizja strukturalizmu pozostaje w zgodzie z rodzajem autorefleksji, której Roland Barthes dał wyraz w słynnym artykule Driałalność strukturalistyczna: „,...] właśnie dlatego, że wszelka myśl o tym, co zrozumiałe, jest także udziałem w tym zrozumiałym, dla człowieka strukturalnego trwanie nie ma większego znaczenia: wie on, że strukturalizm jest także pewną formą świata, która zmienia się wraz ze światem [...]” (Barthes 1970, 281). 


\section{Wykaz literatury}

Barthes, Roland. 1970. „Działalność strukturalistyczna”. W Roland Barthes. Mit i żnak. Eseje. Tłum. Anna Tatarkiewicz. Warszawa: PIW.

Deleuze, Gilles. 1978. „Po czym rozpoznać strukturalizm?”. W Drogi wspótczesnej filozofii. Wybrał i wstępem opatrzył Marek Siemek. Tłum. Stanisław Cichowicz. Warszawa: Czytelnik.

Deleuze, Gilles. 2007. „Rozmowa o »L'Anti-CEdipe« (wspólnie z Féliksem Guattarim)”. W Gilles Deleuze. Negocjacje 1972-1990. Tłum. Michał Herer. Wrocław: Wydawnictwo Naukowe Dolnośląskiej Szkoły Wyższej Edukacji TWP we Wrocławiu.

Deleuze, Gilles. 2007. „Stawanie się i kontrola”. W Gilles Deleuze. Negocjacje 1972-1990. Tłum. Michał Herer. Wrocław: Wydawnictwo Naukowe Dolnośląskiej Szkoły Wyższej Edukacji TWP we Wrocławiu.

Descombes, Vincent. 1997. To samo i inne. Cqterdzieści pię́ lat filozofii francuskiej (1933-1978). Tłum. Bogdan Banasiak i Krzysztof Matuszewski. Warszawa: Spacja.

Dosse, François. 1997. History of Structuralism. Vol. 1: The Rising Sign. 1945-1966. Tłum. Deborah Glassman. Minneapolis-London: University of Minnesota Press.

Foucault, Michel. 2002. Archeologia wiedzy. Tłum. Andrzej Siemek. Warszawa: DeAgostiniAltaya.

Foucault, Michel. 2007. Stowa i rzeczy. Archeologia nank bumanistycznych. Tłum. Tadeusz Komendant. Gdańsk: słowo/obraz terytoria.

Foucault, Michel. 2013. „Kiedy przestał pan wierzyć w sens?”. W Michel Foucault. Kim pan jest, profesorze Foucault? Debaty, rozmowy, polemiki. Red. Bartłomiej Błesznowski, Kajetan Maria Jaksender, Krzysztof Matuszewski. Tłum. Kajetan Maria Jaksender. Kraków: Libron/Eperons-Ostrogi.

Strozier, Robert. 2013. "Saussure and the Intellectual Traditions of the Twentieth Century." W Ferdinand de Saussure. Critical Assessments of Leading Linguists. T. 3: Saussure, Structuralism and Post-Structuralism. Red. John E. Joseph. London \& New York: Routledge.

Topolski, Jerzy. 1977. Marksizm i bistoria. Warszawa: PIW. 
CYTOWANIE: Błesznowski, Bartłomiej. Strukturalizm i historia. Praktyka Teoretyczna 4(22): 8-15.

DOI: $10.14746 /$ prt.2016.4.1

AUTHOR: Bartłomiej Błesznowski

TITLE: Structuralism and History

ABSTRACT: A short introduction of the issue of the Theoretical Practice Journal. 